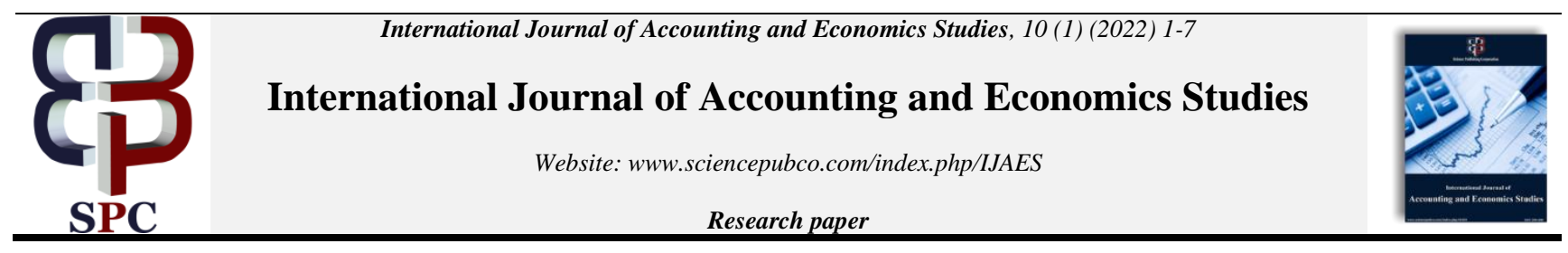

\title{
Relevance of statement of cash flow in the measurement of corporate financial performance
}

\author{
Izevbigie D.P.I. Ph.D. ${ }^{1}$ *, Ikhu-Omoregbe G.O. Ph.D. ${ }^{1}$ \\ ${ }^{1}$ Department of Accounting Faculty of Management Sciences, University of Benin, Benin City, Nigeria \\ *Corresponding author E-mail: Pedroyankee@yahoo.com
}

\begin{abstract}
The objective of this paper is to examine the relevance of statement of cash flow in the measurement of corporate financial performance. The methodology is secondary source through library based research and the review of relevant and extant literature, after which conclusion and recommendations were preferred.

It is evident based on the review of literature that the statement of cash flows is yet to attain adequate relevance in the financial reporting environment due to some inherent problems such as lack of financial accounting literacy on the part of some non-accountant investors, the over-emphasis on the use of profit as a standard measure of performance by regulatory authorities, and limited attention given to the statement in the course of auditing financial statements. It is therefore recommended that the Financial Reporting Council of Nigeria (FRCN) and professional bodies should put stiffer penalties in place to reduce problem of material misstatement, so as to ensure that the cash flow figures as reported present the true and fair view. The basis of preparation of statement of cash flows should make relevant adjustment for inflation through the use of either current purchasing power approach or current cost accounting particularly for industrial organisations during the period of hyperinflation in an economy in order to increase its relevance.
\end{abstract}

Keywords: Use about five key words or phrases in alphabetical order, Separated by Semicolon.

\section{Introduction}

Corporate financial performance is how well an organisation is able to generate sufficient returns on its investment, as well as improving the wealth of stakeholders. Measurement of corporate financial performance could be in terms of profitability, liquidity, or networth metrics depending on the intent of the users of such information. These performance metrics could be derived from ratios computed on values derivable from each of the different financial statement or integrated financial statements as the case may be. Some of the financial statements based on the provisions of the International Accounting Standards Board (IASB) which gives details about performance of companies are: statement of financial performance which measures the financial performance of an organisation within an accounting year; statement of financial position which gives an impression about the networth; and statement of cash flows which discloses information about corporate liquidity. According to Eyisi and Okpe (2014) statement of cash flows shows cash inflows and outflows, with the objective of disclosing the net liquidity position of an organisation, thus suggesting its relevance in the process of financial reporting.

The statement of cash flow is one of the essential measures of corporate liquidity in financial reporting environment. It is meant to cover up the deception created by the profit or loss figure disclosed by the statement of comprehensive income. Ubesie, Chitor, and Ejembi (2016) opined that cash represents a firm's vascular system and the survival of a firm is largely a function of availability of cash, maintaining that liquidity of a firm is not always equal to profitability. This claim presupposes that profit figure disclosed in a company report does not reflect the true liquid state of the organisation, thus might be deceptive in the long run. The statement of cash flow originated from what was hitherto referred to as statement of source and application of fund as the latter was said to have adopted accrual concept of measuring earnings, and that accrual concept distorts the measure by including factors that will not affect the flow of cash to or from the business activities (Danos \& Imhoff, 1991; Zeff \& Keller, 1985). The statement of cash flows is used to measure corporate liquidity and the components of the statement include cash flows from operating activities; investing activities; and financing activities. The International Accounting Standards (IAS) 7 and Section 334(2) of the Companies and Allied Matters Act (CAMA) 2004 as amended to date provides for the inclusion of statement of cash flow in the financial reports prepared by companies in Nigeria, an indication that the statement of cash flow could be relevant to users of financial information for different purposes.

The relevance of statement of cash flow in financial reporting parlance is premised on the perception of the users alike and the purpose for which the statement is needed in the circumstance. For instance Street and Stanga (1989) emphasised the relevance of segment cash flow in an empirical study in the course of making lending decisions in the United States of America (USA). However in academic discuss, the relevancy of statement of cash flows in the measurement of corporate financial performance has generated serious controversies for over three decades thus culminating in what appears to be unsettled and yet to be resolved academic debate such as (i) Lee (1981); (ii) Egginton (1984); (iii) Lee (1985); (iv) Lawson (1985); (v) Egginton (1985); (vi) Staubus (1989); and (vii) Lee (1990).

These age-long debates on the relevance of statement of cash flows in the measurement of corporate financial performance and its associated rhetorics amongst academics appear unsettled in accounting research. In the light of the raging controversies surrounding the rele- 
vance of statement of cash flows which are summarized in the later part of this review, this paper examined the views of the different scholars and took a position. The paper therefore attempts to examine the relevance of statement of cash flows in the measurement of corporate financial performance in contemporary times in Nigeria. The paper is divided into different sections and subsections which includes literature review on concepts of corporate financial performance, statements of cash flows, history of statements of cash flows, age-long controversies surrounding statement of cash flows, empirical review on the relevance of statement of cash flows, theories, challenges of statement of cash flows in contemporary times relative to age-long controversies raised in this paper, summary and conclusion.

\section{Literature review}

\subsection{Conceptual framework}

This section explains the different concepts which include corporate financial performance as well as its measurements, statements of cash flow and the components of statement of cash flow.

\subsection{Corporate financial performance}

Corporate performance is composite assessment of how well an organisation reports on its important parameters. Corporate financial performance can also be seen as the overall financial wellbeing of an organisation over a given period of time that can be used to compare similar firms across the same industry or to compare industries or sectors in aggregation (Bhunia, Mukhuti, Roy, Harbour, Bengal, \& Delhi, 2011).

Chenhall (2005) discusses some attributes, strengths and the coherence of performance measurement systems, and suggested that management should consider the multiplicity of stakeholders by focusing on relevant measures such as effectiveness, efficiency, and equity, maintaining that performance measurement systems should incorporate financial and non-financial outcomes whilst providing vertical links between strategy and operations, and horizontal links across the value chain of an organisation. Corporate performance is measured in terms of financial and non-financial performance of an organisation (Kaplan, 1983). It is further stated that performance measurement systems should provide information on how an organisation relates to its external stakeholders and its ability to accommodate them in the long run.

David (2005) identifies three stages circle to attain improvements which are strategy planning, strategy implementation (execution) and performance measurement or evaluation. He noted that corporate planning phase involves setting goals and objectives that are in tandem with the corporate vision, mission and value statements of the organisation. Goals and strategies are formulated after a careful and critical analysis of the organisation's internal strengths and weaknesses and also of the organisation's external opportunities and threats, conducted through a Strength, Weakness, Opportunities and Threats (SWOT) analysis, which is also sometimes referred to as corporate analysis. After the corporate analysis, strategies are formulated as a means to achieve the goals that have been set; and that is followed by the implementation of the corporate plans.

Kaplan and Norton (1992) developed the Balanced Scorecard model in an attempt to address limitations associated with financial measurement systems, which are prone to abuse by top management. Apart from combining both financial and non-financial measures, the Balanced Scorecard model is conceptualised on the maxim of the maximisation of shareholders value. The Balanced Scorecard model is governed by the set prescriptions and procedures that an organisation has to follow in order to "maximise" a shareholder's investment. Financial performance could be measured in terms of return on assets and return on equity.

\subsection{Return on assets}

According to Heikal, Khaddafi, and Ummah (2014), Return on Assets (ROA) is the ability for the company to utilize its assets to generate sufficient returns by way of sufficient profit.

\subsection{Return on equity}

Return on Equity (ROE) measures the extent to which the firm maximize the wealth of shareholders by improving on the capital contributed by shareholders. It is a measure of profit over total equity (Kabajeh, Alnu'aimat, \& Dahmash, 2012).

\subsection{Statement of cash flows: meaning and history}

Osirim (2017) defines cash flow as an index of the money that is either paid or received which exclude non-cash items such as depreciation, bonus issue of shares, refinancing of debt instruments, exchange of non-momentary assets, conversion of financial instruments and others. He opined that the statement of cash flow is segmented into operating, investing and financing activities. According to Uremadu (2004) cash flows of an organisation are pool of funds that the company uses in financing its fixed assets, inventories, account receivables and marketable securities that generates corporate profit.

Adelegan (2003) defines cash flows as more direct measure of corporate liquidity as well as contributing factor to corporate financial performance. It assist users of financial information in obtaining the relevant information concerning the liquidity of organisations over a given time period (Ross, WesterField, \& Jordan, 2007). Body and Cortese-Danile (2000) sees cash flow statement as that used by third parties for making credit analysis, solvency estimation, financing of investment requirement and in the evaluation of the quality of income generated as a result of business activities.

According to Davis (2016) the development of capital markets precipitated the need to shift the focus of financial reporting from debt to equity, consequently leading to the increase emphasis on the statement of comprehensive income. In a bid to enhance the collection of corporate taxes and put mechanism in place to evaluate inflation, firms in the early 20th century voluntarily added the statement of funds flow to balance sheet and income statement. The global recognition and adoption regulation of the funds flow statement, and subsequent cash flow statement, was champion by accounting standard-setting bodies within the United States of America (USA), before other countries started adopting it (Donleavy, 1994). Davis (2016) noted that the Fund statement gained popularity in the USA around 1950's to 1960 's, and the popularity was followed by problem of comparison due to non-uniform standard and format of presentation, thus given rise to academic debates. 
In a bid to address this challenges of non-uniformity of standards, Savoie (1965) noted that the American Institute of Certified Public Accountants (AICPA) in 1961 launched Accounting Research Study No. 2 - "Cash Flow" Analysis and The Funds Statement with the mandate to standardize the disclosure and its findings were subsequently responded to in October 1963 by the Accounting Principles Board (APB) leading to the issuance of Opinion No. 3 "The Statement of Source and Application of Funds", with it been a mere recommendation, as it was not to be statutorily disclosed as supplementary accounts to be reported by companies. Davis (2016) noted that in 1971, the APB superseded their prior Opinion No. 3, and issued Opinion No. 19 - "Reporting Changes in Financial Position" mandating the disclosure of a renamed "Statement of Changes in Financial Position" (SCFP) for all companies disclosing an income statement and balance sheet as part of their annual accounts. After a decade of agitations for and against APB No. 19, the FASB issued Statement of Financial Accounting Standards (SFAS) No. 95 "Statement of Cash Flows" which superseded APB No. 19, effective for all companies with financial years ending after July 1988 (FASB, 1987) and coded as ASC 230 Statement of the Cash Flow under the FASB Accounting Standards Codification 230 (ASC 230) beginning from July 1, 2009 (Flood, 2015). The U.S. was one of the first countries to introduce a standard on cash flow disclosure and define it in the form which is widely used to this day (Davis, 2016).

In Nigeria, the historical development of statement of cash flows is similar to the account highlighted above as it was imported from the western orientation, hence the statement of source and application of funds was in used prior to the establishment of the Nigerian Accounting Standards Board (NASB) in 1982, which was given legal teething in 2003 by the Nigerian Accounting Standards Board Act no. 22 of 2003, and subsequently repealed and replaced by the Financial Reporting Council of Nigeria (FRCN) in 2011. The NASB saddled with the responsibility of issuing Statement of Accounting Standards (SASs) as at the time, had earlier issued SAS 18 on statement of cash flows; thereby transited from the era of statement of source and application of funds to the current nomenclature; statement of cash flows. From a legal point of view, the Companies and Allied Matters Act (CAMA) 1990 provided under S.334 (2) for statement of source and application of fund, until 1997 when it was replaced by statement of cash flows.

\subsection{Components of statement of cash flows}

The statement of cash flow is segmented into operating, investing and financing activities. This section reviews the different components of the statement of cash flows.

\subsection{Operating cash flows}

Operating activities are "the principal revenue producing activities of the entity and other activities that are not investing or financing activities" (IAS 7). Operating activities include items as receipts from customers, cash received in the form of interest and dividends from investments, cash payment to employees, cash payment to suppliers, and cash payment for income and other taxes. Accoridng to Fabozzi and Markowitz (2006) operating cash flow represent cash generated or incurred by the core operations of a business activities, and that the net cash flow from operation is a representation of the net increase or decrease in cash and cash equivalent used in determining the operating profit from the income statement. Operating cash flow is a good and more accurate measure of seeing the performance of a company based on the fact that it makes relevant adjustment for account receivable, liabilities, and depreciation, when compared to profit figure (Fabozzi \& Markowitz, 2006). Bragg (2002) suggests that net cash flow from operating activities is used as a measure of performance, just as net profit.

\subsection{Investing cash flows}

Investing activities are "the acquisition and disposal of long-term assets and other investments not included in cash equivalents" (IAS 7). Broome (2004) defines investing cash flows as cash spent or received with respect to infrastructure and other non-current assets, such as cash payment for procurement of property, plant, and equipment; cash received from the sale of property or equipment; cash paid for long-term investment in securities; and cash received from the sale of long-term investments in securities.

\subsection{Financing cash flows}

Financing activities are "activities that result in changes to the size and composition of the contributed equity and borrowings of the entity" (IAS 7). According to Broome (2004) financing cash flows are cash issued or redeemed to and from creditors and other providers of capital such as payment of dividend, cash received from loans, issue of shares, issue of debenture, stock repurchase, and redemption of shares. Broome (2004) noted that payment of dividend is recommended by the FASB as financing activities based on the fact that dividend is an appropriation item in the statement of comprehensive income as against interest charges which is taking as an operational expenses.

\subsection{Statutory requirements and relevance of statement of cash flows}

The sources of authority that govern financial reporting in Nigeria are both of local and international provisions such as the CAMA 2004 as amended to date, International Financial Reporting Standards (IFRS), GAAP and other sector specific provisions. S.334(2) of the CAMA 2004, an omnibus legislation governing the operations of corporate activities in Nigeria made mandatory the inclusion of statement of cash flows as part of the financial reports checklist required to be prepared by company directors, an indication which tends to emphasis its importance. Similarly, IAS 7; an international standards for statement of cash flows makes provision for the rule of best practices required in the preparation of statement of cash flow.

The statutory provisions listed above tend to underscore the relative importance of the statement of cash flows; however this is not without reservation. First human errors resulting from material misstatement could undermine the relevance of statement of cash flows, similarly the relevant tax authorities for instance are more concern about taxable profits in the statements of financial performance and applicable capital allowances for the qualifying capital expenditures (QCEs) in the statement of financial positions, despite the fact that figures in this reports are not cured of the effect of accruals, why little or no attention is given to the statement of cash flows. This development also tends to raise a question mark on the relevance of statement of cash flows in measuring organisation performance.

\subsection{Controversies on the relevance of statement of cash flows}


The notable controversies on the relevance of statement of cash flows in chronological order are (i). Lee (1981) "reporting cash flows and net realisable values": who made a rare attempt to link Cash Flow Accounting (CFA) and Net Realisable Value Accounting (NRVA), but submitted that each is incomplete without the other, maintaining that cash-orientated system may only have a limited application to certain types of enterprise whose asset structure is mainly composed of readily-realisable assets such as banks, property and insurance companies, while the same may not be said of industrial companies, hence a limitation of cash flow statements; (ii). Egginton (1984) on the contrary, defended the use of profit as a measure of corporate financial performance citing some limitations of cash flow and value added as performance measures for external reporting to include inability to summarise the accretion in corporate resources which is included in an all-inclusive profit measure based on entry or exit values, non-reflection of the consumption of resources in operations, as does current operating profit, do not compare well in all respects with historical cost profit, ignores movements in non-cash elements, and lack of satisfactory position statement.

Further debates on the relevance of statement of cash flow are (iii). Lee (1985) "Cash Flow Accounting, Profit and Performance Measurement: A Response to a Challenge", who attacked the position of Egginton (1984) and submitted that in an appeal to sentiment shared with the views of Kaplan (1983), most organisations under-estimate other performance indicators such as productivity, market domination, and quality of products and services, hence the obvious reason why Egginton would think of excluding liquidity index as a performance measure; (iv). Lawson (1985) "The measurement of corporate financial performance on a cash flow basis: A reply to Mr. Egginton" also join the attack of Egginton maintaining the importance of statement of cash flows as a measure of corporate financial performance; and (v). Egginton (1985) "Cash flow, profit and performance measures for external reports: A rejoinder" in response to Lawson and Lee, argued that the duo recognized the fact that cash flows alone are not enough, hence the need for the incorporation of some change in value of unexpired benefits into statement of cash flows for external reporting, hence the justification for the defence argument in favour of profit measurement, thus a consensual position, suggesting that Lawson and Lee were in disagreement on whether market values or Net Realisable Values (NRVs) will be the basis for valuation respectively.

In continuation of the debate, (vi). Staubus (1989) "Cash Flow Accounting and Liquidity: Cash Flow Potential and Wealth" expressed the need to separate liquidity and wealth in the context of considering the relative advantages of alternative prescriptions for external financial reporting. He asserted that CFA external financial reports have potential value for assessing liquidity, but not suitable for performance in terms of changes in wealth; and finally (vii) Lee (1990) "Restricting the Domain and Potential of Cash Flow Accounting" opposed the views of Staubus (1989) on CFA maintaining that his views were synonymous to that of Egginton, and that he defines the general prescription for CFA reporting strictly in terms of historical or realised cash flows (HCFA), and that the CFA reporting perspective Staubus aims to provide was incomplete and secondly, Staubus fails to critique either HCFA or total cash flow accounting (TCFA) within the frame of an explicit statement of qualitative accounting criteria.

\section{Theoretical framework}

\subsection{Agency Theory}

Jensen and Meckling (1976) developed this theory when they tried to examine the nexus that exist between investors and managers. This followed an earlier attempt in the year 1949 in the publication by an Italian Professor Aldo Amaduzzi, in his book published and titled, Conflitto ed equilibrio di interessi nel bilancio dell'impresa' (with an English translation, Conflict and Equilibrium of Interests in Corporate Financial Statements), wherein he analysed financial reports as the equilibrium outcome of the inherent conflicting interest between different stakeholders in an establishment.

The agency theory has direct bearing on this study based on the fact that the statement of cash flows is supposed to convey information about the true and fair liquid position about organisations' liquidity to investors due to inherent integrity gap caused by the present of principal-agent relationships, hence, the different users of the financial statements have subjective interpretation on the content of each financial statements.

\section{Empirical review}

The empirical review below examines the relevance of statement of cash flows in the measurement of corporate financial performance in terms of its predictability of business performance, failure, lending decision, and sustainability.

Kwok (2002) examined the effect of cash flow format on lending decision in China. The study examined bank loan officers' use of annual reports with particular emphasis on statement of cash flows. Sample of four groups of frequent users of financial reports including bank loan officers, auditors, financial analysts and accounting academics were asked to make independent judgment about lending decisions about annual reports of two loan applicant companies based on the information before them. The statement of cash flow of one of the companies was presented in the direct format, while the other was presented in the indirect format thus serving as a surrogate for funds flow statement. The study found that statement of cash flow was the second most used financial information, with the statement of financial position been the most used financial statement, while note to the account was also more frequently used than the statement of cash flows. In terms of format of presentation, no emphasis was placed on the direct method. On the average the finding of the study suggest less relevance of the statement of cash flows in making lending decisions. The reason for the less relevance on statement of cash flow in making lending decision could be based on the fact that lending decision in China is informed by other financial information order than liquidity.

Sharma and Iselin (2003) conducted a behavioural field experiment in Australia on the usefulness of reported cash flows and accrual information. The study used a sample of two groups; which comprises of bankers having a minimum of three year work experience who made solvency judgments on the basis of either cash flows or accruals. The study found out that decision made on the basis of cash flows was more relevant than those made on the basis of accruals, while these decisions were more obvious in failed (insolvent) organisations compared to solvent organization. Their decision has limitation, in that their conclusion only emphasizes situation of companies' distress, hence unclear whether cash flows based decision will be effective in for a going concern.

Ryu and Jang (2004) investigated the use of cash ratios and traditional ratios as a measure of performance of organization in the United States of America. The study cover a five years period, while financial data of commercial hotel and Casino hotel were used for comparative analysis. Thee research data were generated from the Mergent Online with SIC 7011. The result of estimation conducted with sample t-tests after adopting relevant proxies for performance measurements such as liquidity, solvency, and operational efficiency indicators, shows significant differences between traditional ratios and cash flows based rations, thus point to the fact that the differences is 
associated with nature of the hotel. The findings of the study further buttress the dynamics associated with the use of statement of cash flows as a measure of performance. It is pertinent to state that the relevance of statement of cash flows could be largely premised on the nature of organisation.

Jooste (2006) carried out a comparative study between emerging economy and developed society using South Africa and USA as a case study. The study placed emphasis on chemical, food, and electronic industries; with the focus on cash flow ratios. The study computed nine ratios in line with the Giacomino and Mielke approach based on the industries for the period covering 1986-1988, and the relevant industry norms were computed for the period as way benchmark. Findings from the study show that there are similarities and differences. The study show evidence of the fact that cash flow sufficiency ratio revealed that SA firms could meet it primary obligation as against their US counterpart, while it was also revealed that SA firms generated more cash flow from asset as against US.

Amuzu (2010) examined the use of cash flow ratio as a measure of performance in Ghana using qualitative and action research methodology. The study used individual data points of three years covering the period 2003-2005. The study shows that Ghanaian companies are as competitive as US companies in terms of cash flow ratios in the same industries. However, Ghanaian companies did better as compared to their US counterparts. In terms of industry performance and nexus with statement of cash flows, Ghana was seen to be more competitive in the Milk Products and Alcoholic Beverages industry, while US did better in Telecommunications Industry. The differences across industry line on the relevant of cash flow ratios could be a function of the difference in accounting treatment relating to the industries activities or the comparative advantage enjoy by different countries. For instance, the US has intellectual property culminating in advancement of technology, thus could explain the reason for the significant nexus between the variables under consideration.

Miranda-Lopez and Nichols (2012) examined the used of earnings and cash flows in investment decisions in the United States of America (U.S.A) and Mexico by non-professional investors following the stagnated growth of the Mexican stock market. Experimental methodology was used to test the research hypotheses. The sample of the study is one hundred and ninety three (193) participants which comprises of senior level undergraduate accounting majors and MBA students including eighty (89) in the U.S.A and 104 in Mexico. Using chi-square and Analysis of Variance (ANOVA) tests for statistical estimation, the study revealed that the majority of participants in the U.S.A uses earnings while participants in Mexico uses cash flows in the measure of performance. This finding could be premised on the nature and state of the capital markets of the different countries, and the differences in accounting choices further justifies the age-long controversies on what constitutes the relevance of statement of cash flows.

Bhandari and Iyer (2013) conducted a study in the United States of America (USA) on predicting business failure using cash flow statement based measures during the period of economic covering 2008-2010. Considering the fact that prior predictor model were built around accrual-based accounting figures, the authors built a new model using mostly cash flow statement based measures as predictor variables and discriminant analysis technique. Data of one hundred (100) firms were used as sample size including 50 "failed" firms matched with 50 non-failed firms according to Standard Industrial Classification (SIC) code, while financial statement data for the year prior to failed year were pulled from COMPUSTAT database. The study used seven predictor variables which include: Operating cash flow divided by current liabilities, Cash flow coverage of interest, Operating cash flow margin, Operating cash flow return on total assets, Earning quality, Quick ratio and Three-year sales growth. Using SPSS-19 software to perform discriminant analysis (DA), the study found out that the DA model classified 83.3 percent of original grouped cases correctly, while the jackknife or leave-one-out method(cross-validated approach) correctly classified 79.5 percent of cases. The chi-square test of Wilks' lambda was significant at 0.000 level which means the model as a whole performed very well in predicting business failure. The finding in this study is suggestive of the fact that the statement of cash flows is relevant for predictability of business failure. However the predictor model based on cash flow based ratios may not be optimal in times of inflation, since the figures making up the statement of cash flows are not cure of the effect of inflation.

Ubesie, Chitor, and Ejembi (2016) examines the nexus between cash flow and performance in the Nigeria's Food and Beverages sector through a survey of Six (6) quoted companies on the Nigerian Stock Exchange. Secondary data were gathered from annual reports of the selected companies, while multiple regression estimation was used for data analyses. Findings from the estimation show that there is a significant and positive relationship between operating, and financing with corporate financial performance respectively, while investing cash flow showed a significant and negative relationship with corporate financial performance. The study however recommended need for regulatory authorities such as Financial Reporting Council of Nigeria (FRCN), Central Bank of Nigeria (CBN), IFRS, Nigerian Stock Exchange (NSE), Security and Exchange Commission (SEC), and Nigeria Deposit Insurance Corporation (NDIC), to prevail on external auditors to base their opinion on findings from the statement of cash flows. The assumption of the study based on their recommendation appears to fault the process of forming audit opinion, hence suggesting the fact that the audit opinion is based on findings from other statements other than the statement of cash flows, a submission that may not be completely correct since the law requires the external auditor to base his audit opinion on findings from the review of the books of accounts including statement of cash flows.

Lee, Glasscock, and Park (2017) examine whether the association of Operating Cash Flows (OCF) with stock returns improves significantly for financially distressed firms, when compared to the association between earnings and stock returns. They submitted that for financially distressed firms, OCF are more strongly associated with returns than earnings. Thus found out that OCF, rather than earnings, are more strongly associated with stock returns during periods of firm-specific financial distress. The study also provides evidence that the strength of the observed return-OCF relation increases in a market-wide crisis. The Shapley value analysis consistently shows that OCF are relatively more important with respect to stock returns than earnings for financially distressed firms. Overall, their findings support the perspective that investors find OCF information more useful than that of earnings, in both firm-specific financial distress and market-wide crisis periods. The findings of the study supporting the view that OCF is more useful than earnings failed to acknowledge the fact that different investors could be interested in different measurement or appraisal index, as well as the nature of capital market wherein the organisation is listed.

Chukwunwike, Ofoegbu, Okoroiwu, and Okafor (2018) study the impact of statement of cash flow on corporate financial performance. The explanatory variables included operating, investing and financing activities, while reported profit was taken as the explained variable of the study. The study used ten (10) years panel data for the period 2007-2016 of banks quoted on the floor of the Nigeria Stock Exchange, while quasi-experimental research design was adopted. Estimation was carried out using multiple regression analyses with the aid of STATA econometric software and the result shows that there is a significant and positive nexus between statement of cash flows and corporate profit. It was also found that there is insignificant and positive relationship between the different explanatory variables and explained variable respectively. The study concluded that statement of cash flows is not a good measure of corporate financial performance. The finding of the study is the outcome of a specific sector, hence may not be suitable in making necessary generalisation. In the same vein this finding contributes to conflicting positions in literature on the subject matter, thus justifying the controversies on the relevance of statement of cash flows in measuring financial performance. 
Nwaiwu and Macgregor (2018) examine the causal effect of cash flow accounting on profitability. The study took data of five (5) years covering the period 2008-2012 of twenty four (24) companies listed on the floor of the Nigerian Stock Exchange (NSE). Estimation was carried out using Pearson Product Moment Correlation Coefficient, Multiple Regression and Partial Correlation Coefficient. The estimation revealed that there is significant and positive nexus between cash flow accounting on gross profit of quoted firms in Nigeria. The study findings is suggestive of the fact that the statement of cash flows has significant relevant in the measurement of performance of organization. However, the sample of 24 companies with a period of 5 years observation may amount to weak methodology as findings from such population may not be healthy in arriving at good generalisation.

Adame, Koski, and McVay (2019) investigated why investors are paying more attention to free cash flows by trying to established if this is as a result of increased information content of free cash flows, a paradigm shift towards firms for which cash flows is value relevant, or correction of past market reaction towards cash flow news. Their study provide for higher responsiveness on the part of new firms with more intangibles and those that also discloses free cash flows as part of their earnings announcements on the average. It was further revealed that changes in responses to free cash flow has to do with changing economic and not learning, and there was no evidence of mispricing free cash flows surprises. The study also noted that in the event of inconsistency between earnings and free cash flows signals, free cash flows are price in firms having high intangibles. The study thus shows the importance of free cash flows.

\section{Challenges of statement of cash flows in contemporary times relative to the age-long contro- versies raised in this paper}

The statement of cash flows in the context of financial reporting in contemporary times forms an integral aspect of disclosure requirements in financial reporting environment as provided for in IAS 7 and S.334(2) of CAMA 2004 as amended to date. However its degree of relevance in the accounting profession appears yet to have been fully justified on account of human factors, collusion, and management override of control in the course of preparation of the statement of cash flows. This human factors or material misstatements may have prevented the statement of cash flows from bridging the inherent lacuna created by the illusive profit and loss figure that is usually reported by statement of financial performance, which has caused monumental corporate failure such as in the cases of Enron, Worldcom, Adelphia, Oceanic bank, Intercontinental bank and others, it does appear that the statement of cash flows is yet to gain the desired relevance.

However, this apparent challenge of the statement of cash flows caused by human error may be driven by an appeal to the sentiment expressed in the works of Egginton $(1984,1985)$ which severely criticized statement of cash flows in terms of it lacking the needed information robustness required to substitute the statement of financial performance as a viable alternative in eliminating any deception that is inherent in the statement of financial performance.

The challenges associated with the statement of cash flows in terms of performance measurement are enormous, despite statement of cash flow being an integral aspect of financial reporting. The way forward could be for the different accounting regulatory authorities to put stiffer penalties in place to reduce problem of material misstatement, so as to ensure that the cash flow figures as reported present the true position. Furthermore the basis of preparation of statement of cash flows should make relevant adjustment for inflation through the use of current purchasing power approach or alternatively apply current cost accounting particularly for industrial organisations for preparation of the statement of cash flows in order to increase its relevance.

\section{Summary and conclusion}

This paper examines the relevance of statement of cash flow in measuring corporate financial performance through a review of extant and related literature. The paper was motivated by raging controversies which ensued for over three decades among accounting scholars on the relevance of statement of cash flows putting forward some basis to support their arguments. In a bid to contribute to knowledge and close gaps created by the controversies in the light of innovation that has evolved since the time of their debates such as the internationalisation of accounting standards; IFRS, and amendment to corporate laws, this paper looks at conceptual issues on corporate financial performance and statement of cash flows, a brief history of the statement of cash flows was also examined, some empirical evidence on the relevance of statement of cash flows were also examined, and the place of statement of cash flows within statutory provisions were also considered. After careful review of literature, it is evident that the statement of cash flows is yet to attain adequate relevance in the financial reporting environment due to some inherent problems such as lack of financial accounting literacy on the part of some nonaccountant investors.

It is therefore recommended that the Financial Reporting Council of Nigeria (FRCN) and professional bodies should put stiffer penalties in place to reduce problem of material misstatement, so as to ensure that the cash flow figures as reported present a true and fair view. The basis of preparation of statement of cash flows should make relevant adjustment for inflation through the use of either current purchasing power approach or current cost accounting particularly for industrial organisations during the period of hyperinflation in an economy in order to increase its relevance.

\section{References}

[1] Adame, K., Koski, J., \& McVay, S. (2019). Why are investors paying more attention to free cash flows? University of Washington.

[2] Adelegan, O.J. (2003). An empirical analysis of the relationship between cash flow and dividend charges in Nigeria. Journal of Research in Development and Management, 15, 35-49. https://doi.org/10.1111/1467-8268.00061.

[3] Amuzu, M. S. (2010). Cash flow ratio as a measure of performance of listed companies in emerging economies: The Ghana example. A dissertation submitted in fulfilment of the requirement for the Degree of Doctor of Philosophy, St. Clements University Turks and Caicos Islands.

[4] Bhandari, S. B. \& Iyer, R. (2013).Predicting business failure using cash flow statement based measures. Managerial Finance, 39(7), 667-676. https://doi.org/10.1108/03074351311323455.

[5] Bhunia, A., Mukhuti, S. S., Roy, S. G., Harbour, D., Bengal, W., \& Delhi, N. (2011). Financial performance analysis-A case study. Current Research Journal of Social Sciences, 3(3), 269 -275. https://doi.org/10.5296/jmr.v3i2.574.

[6] Body, T., \& Cortese-Danile, T.M. (2000).Using the cash flow statement to improve credit analysis. Commercial Lending Review, 16(1), 55-59.

[7] Bragg, S. M. (2002). Business ratios and formulas: a comprehensive guide. New York.

[8] Broome, O.W. (2004).Statement of cash flows: Time for change! Financial Analysts Journal, 60(2), 16-22, https://doi.org/10.2469/faj.v60.n2.2605. 
[9] Chenhall R. (2005). Integrative strategic performance measurement system, strategic alignment of manufacturing, learning and strategic outcomes: An exploratory study. Accounting, Organisation and Society, 30, 395-422. https://doi.org/10.1016/j.aos.2004.08.001.

[10] Chukwunwike, O.D., Ofoegbu, G.N., Okoroiwu, K.L., \& Okafor, R.G. (2018).The potency of cash flow in predicting corporate financial performance. Account and Financial Management Journal, 3(6), 1591-1601. https://doi.org/10.31142/afmj/v3i6.06.

[11] Companies and Allied Matters Act (CAMA) 1990 Laws of the Federation of Nigeria, 1990

[12] Companies and Allied Matters Act (CAMA) 2004 Laws of the Federation of Nigeria, 2004

[13] Danos, P. \& Imhoff, E. A. (1991). Introduction to Financial Accounting. Boston: Richard D. Irwin, Inc.

[14] David, F.R. (2005). Strategic Management: Concepts and Cases. Prentice Hall, Pearson Education International, 10th edition.

[15] Davis, O. (2016). Statement of cash flows: Issues in cash flow reporting in Estonia. Master Thesis, Tallinn University of Technology, School of Economics and Business Administration, Department of Accounting, Chair of Management Accounting

[16] Donleavy, G. (1994). Cash Flow Accounting: International Uses and Abuses. London: Routledge.

[17] Egginton, D. A. (1984).In defence of profit measurement: Some limitations of cash flow and value added as performance measures for external reporting. Accounting and Business Research, 14(54), 99-111. https://doi.org/10.1080/00014788.1984.9729197.

[18] Egginton, D. A. (1985).Cash flow, profit and performance measures for external reports: A rejoinder. Accounting and Business Research, 15(58), 109-112. https://doi.org/10.1080/00014788.1985.9729254.

[19] Eyisi A. S. \& Okpe I.I. (2014). The impact of cash flow ratio on corporate performance. Research Journal of Finance and Accounting, 5(6), 149158.

[20] Fabozzi., F. J. \& Markowitz, H. M. (2002). The theory and practice of investment

[21] FASB. (1987). Financial Accounting Standards. Statement of Financial Accounting Standards No. 95 Statement of Cash Flows. . Norwalk: Financial Accounting Standards Board.

[22] Flood, M.J. (2015). GAAP 2015, Interpretation and Application of Generally Accepted Accounting Principles. Norwalk, Connecticut, USA: Wiley and Sons Ltd, pp. 83-101. https://doi.org/10.1002/9781119216698.

[23] Heikal, M., Khaddafi, M., \& Ummah, A. (2014). Influence analysis of return on assets (ROA), return on equity (ROE), net profit margin (NPM), debt to equity ratio (DER), and current ratio (CR), against corporate profit growth in automotive in Indonesia stock exchange. International Journal of Academic Research in Business and Social Sciences, 4(12), 101-114. https://doi.org/10.6007/IJARBSS/v4-i12/1331.

[24] IAS (7). International Accounting Standards on Statement of Cash Flows.

[25] Jensen, M.C., \& Meckling, W.H. (1976). Theory of the firm: Managerial behavior, agency costs and ownership structure. Journal of Financial Economics, 3(4), 305-360. https://doi.org/10.1016/0304-405X(76)90026-X.

[26] Jooste, L. (2006).Cash flow ratios as a yardstick for evaluating financial performance in African businesses. Managerial Finance, 32 (7),569 -576. https://doi.org/10.1108/03074350610671566.

[27] Kabajeh, M. A. M., Alnu'aimat, S. M. A. \& Dahmash, F. N. (2012). The relationship between the ROA, ROE and ROI ratios with Jordanian insurance public companies market share prices. International Journal of Humanities and Social Science, 2(11), 115-120.

[28] Kaplan, R. S. (1983). Measuring manufacturing performance: A new challenge for managerial accounting research. The Accounting Review. https://doi.org/10.1007/978-1-4899-7138-8 14.

[29] Kaplan, R. S. \& Norton. (1992). The balanced scorecard measures that drives performance. Harvard Business Review, 70 (1), $71-79$.

[30] Kwok, H. (2002).The effect of cash flow statement format on lenders' decisions. The International Journal of Accounting, 37, $347-362$. https://doi.org/10.1016/S0020-7063(02)00171-1.

[31] Lawson, G. H. (1985).The measurement of corporate financial performance on a cash flow basis: A reply to Mr. Egginton. Accounting and Business Research, 15(58), 99-108. https://doi.org/10.1080/00014788.1985.9729253.

[32] Lee, T. A. (1981).Reporting cash flows and net realisable values. Accounting and Business Research, 11(42), 163-170. https://doi.org/10.1080/00014788.1981.9729693.

[33] Lee, T. A. (1985).Cash flow accounting, profit and performance measurement: A response to a challenge. Accounting and Business Research, 15(58), 93-97. https://doi.org/10.1080/00014788.1985.9729252.

[34] Lee, T. A. (1990).Restricting the domain and potential of cash flow accounting. Accounting and Business Research, 20(80), 355-358. https://doi.org/10.1080/00014788.1990.9728894.

[35] Lee, J. E., Glasscock, R., \& Park, M. S. (2017).Does the ability of operating cash flows to measure firm performance improve during periods of financial distress? Accounting Horizons, American Accounting Association, 31(1),23-35. https://doi.org/10.2308/acch-51594.

[36] Miranda-Lopez, J.E. \& Nichols, L.M. (2012).The use of earnings and cash flows in investment decisions in the U.S. and Mexico: Experimental evidence. Journal of International Accounting, Auditing and Taxation, 21,198-208. https://doi.org/10.1016/j.intaccaudtax.2012.07.008.

[37] Nwaiwu, J. N. \& Macgregor, T.C. (2018). $21^{\text {st }}$ century cash flow accounting and financial performance of quoted companies in Nigeria. International Journal of Advanced Academic Research, 4(2), 25-38.

[38] Osirim, M. (2017).The relevance of the statement of cash flows in the decision making of business organisations: The experience of the banking industry in Nigeria. Business, Management and Economics Research, 3(9), 151-158.

[39] Ross, S. WesterField, R., \& Jordan, B. (2007). Fundamental of corporate finance. New York: Pearson - Patience.

[40] Ryu, K. \& Jang, S. (2004).Performance measurement through cash flow ratios and traditional ratios: A comparison of commercial and casino hotel companies. The Journal of Hospitality Financial Management, 12(1), 15-25, https://doi.org/10.1080/10913211.2004.10653783.

[41] Savoie, L. (1965). The accounting principles board: What it is, how it works and what its role in business is. Financial Analysts Journal, $21,53-57$. https://doi.org/10.2469/faj.v21.n3.53.

[42] Sharma, D. S. \& Iselin, E. R. (2003). The decision usefulness of reported cash flow and accrual information in a behavioural field experiment. Accounting and Business Research, 33(2), 125-135. https://doi.org/10.1080/00014788.2003.9729639.

[43] Staubus, G. J. (1989).Cash flow accounting and liquidity: Cash flow potential and wealth. Accounting and Business Research, 19(74), 161-169. https://doi.org/10.1080/00014788.1989.9728846.

[44] Street, D. L. \& Stanga, K. G. (1989).The relevance of a segment cash flow statement in lending decisions: An empirical study. Accounting and Business Research, 19(76), 353-361. https://doi.org/10.1080/00014788.1989.9728864.

[45] Ubesie, M. C., Chitor I. L., \& Ejembi, E. A. (2016).Effect of cash flow statement on performance of selected food beverage companies in Nigeria. IDOSR Journal of Current Issues in Social Sciences, 2(1), 47-54.

[46] Uremadu, S.O (2004). Financial management: Concepts, analysis and applications. Enugu, precision publisher limited.

[47] Zeff, S. A. \& Keller, T. F. (1985). Financial Accounting Theory Issues and Controversies. New York: McGraw-Hill Inc. 